\title{
Religious Language
}

\begin{tabular}{|r|l|}
\hline Journal: & Philosophy Compass \\
\hline Manuscript ID: & PHCO-0225 \\
\hline Manuscript Type: & Article \\
\hline Keywords: & $\begin{array}{l}\text { Philosophy of Religion }<- \text { Compass sections, Philosophy of } \\
\text { Kanguage < Logic and Language }<\text { Philosophy }<\text { Subject, God }< \\
\text { meaning < Key Topics, truth < Key Topics }\end{array}$ \\
\hline
\end{tabular}

\section{5) scholarONE \\ Manuscript Central}




\title{
RELIGIOUS LANGUAGE
}

\begin{abstract}
This paper reviews some of the principal themes in contemporary work on religious language. Unlike other recent surveys, the most pressing issues about religious language are addressed from the perspective of the philosophy of language; different positions taken on these issues by philosophers of religion and theologians are considered. Topics that are covered include: the subject matter of religious discourse, reductionism and subjectivism, expressivism, the nature of religious metaphor, religious fictionalism, and truth in religious discourse. The paper also looks at the relationship between questions about religious language and cognate areas of philosophy of religion such as epistemology and metaphysics, and potential future directions of research.
\end{abstract}

The following short review of research on religious language will set out some of the principal themes that have been the focus of work in this field over the last century. Recent surveys of religious language have tended to detail the historical development of discussion of the topic within philosophy of religion (Wynn, Stiver, Alston 'Religious Language'). This paper, in contrast, will address the most pressing issues about religious language from the perspective of the philosophy of language and consider the different positions taken on these issues by philosophers of religion and theologians. Consequently we will spend rather less time than is usual on the implications of logical positivism (which is historically interesting but has not been a live issue in philosophy for decades), and look in more detail at questions about content and truth. In the course of this, we will consider the relationship between questions about religious language and cognate areas of philosophy of religion such as epistemology and metaphysics, and potential future directions of research.

\section{What is the topic?}

Here is a prima facie plausible initial characterisation of the aim of research on religious language: we are looking to give a general account of the meaning of religious sentences. Religious sentences are sentences with a religious subject matter, i.e., they concern supernatural agents 
(God, other deities, angels, etc.), the actions of such agents (miracles, creation, redemption, etc.), and supernatural properties and states of affairs (holiness, heaven and hell, etc.). A general account of their meaning will include: (1) the truth conditions for religious sentences (are there defensible reductionist or subjectivist accounts?); (2) whether indicative religious sentences are truth-apt or have propositional content (or do they express beliefs or merely attitudes?); (3) if indicative religious sentences are truth-apt how should we construe the truth for which they are apt? (4) The meaning of religious terms and how they combine to form meaningful sentences (is 'God' a referring expression?). Answering these questions would give us the principal components of a semantic theory for religious language. As we will see in the following sections, a great deal of contemporary work on religious language addresses one or more of these questions. We will look at the first three questions in turn in the following three sections; the last question will crop up in several parts of this paper.

Some philosophers are sceptical about the prospects of developing a semantic theory and favour a pragmatic theory. On this alternative approach, there is no informative account of the meaning of religious sentences because their meaning is highly sensitive to the context of utterance. ${ }^{1}$ Instead, we should aim to give an account of the meaning of religious utterances. ${ }^{2}$ For example, William Alston denies that there is any such thing as religious language and thinks that the only philosophically interesting questions in this field concern religious 'speech' or discourse (i.e. a class of utterances rather than sentences). Alston proposes that the proper subject matter for researchers on religious 'language' is token sentences uttered in religious contexts rather than sentences with a religious subject matter. He takes this to be so basic and evident, in fact, that he contends that philosophers working on religious 'language' have misunderstood and misdescribed their own enterprise:

What is erroneously called religious language is the use of language (any language) in connection with the practice of religion - in prayer, worship, praise, thanksgiving, confession, ritual, preaching, instruction, exhortation, theological reflection, and so on. ('Religious Language', 220)

Another supporter of a pragmatic account of religious discourse is Ludwig Wittgenstein. ${ }^{3}$ For instance, he claims that a religious believer who asserts 'There will be a Last Judgement' is not contradicted by a non-believer who denies it (Lectures and Conversations 55). However, 
the sentence 'There will not be a Last Judgement' is the negation of the sentence 'There will be a Last Judgement'. So he must presumably be talking about the meaning of utterances rather than sentences, and the implication of his example (and others that he gives) is that the meaning of these utterances is in part determined by such contextual factors as the beliefs of the speaker. Accordingly, Wittgenstein suggests that when a religious person says 'There will be a Last Judgement' and a nonreligious person says the same thing - because, say, she believes that there is scientific evidence that it will happen - they will mean different things.

The reader should not be swayed toward the pragmatic approach by the obvious fact that context is relevant to meaning! It is entirely compatible with a semantic theory of religious sentences that there should be important additional things to say about the meaning of religious utterances. Two pervasive pragmatic effects to which any satisfactory account of religious discourse should be particularly attentive are, first, religious metaphor and, second, the use of token religious sentences to convey emotions and other affective mental states. ${ }^{4}$ In a religious metaphor like 'God is my rock', one utters a token religious sentence (that is literally false) with the intention of suggesting or implying something other than what is said. And religious sentences are often used to express the religious feelings of the speaker and inspire similar feelings in the audience. A semantic theorist will certainly want to supplement an account of the semantic content of religious sentences with an explanation of their uses. Where the semantic theorist disagrees with the pragmatist is in (a) insisting on a principled distinction between what a sentence means and what a speaker means by a sentence, and (b) believing that an account of the former has an ineliminable role in a satisfactory theory of meaning.

By developing a semantic theory of religious language first and look at the pragmatic features of religious utterances second, we begin by specifying a content of religious sentences that is (to a degree) insensitive to context. If it were not possible to specify this content - if the content of religious claims were constantly subject to variation according to the context of utterance - it becomes harder to see how meaningful communication is possible (Capellen and Lepore, 123-127). Moreover, a pragmatic account of what utterances count as religious seems implausible. Consider, for example, the vast range of different topics that can be raised in utterances in 'thanksgiving, confession, ritual, preaching, instruction, exhortation' etc. In general, we exclude most of these utterances as the proper topic of philosophy of religion because they do not articulate sentences that have a religious subject matter. It is particularly notable that both Alston and Wittgenstein, in their own work 
on religious discourse, concern themselves exclusively with examples of utterances that have a religious subject matter.

\section{Reductionism and subjectivism}

What are the truth conditions for religious sentences? The correct account of this might seem pretty obvious: 'God is omnipotent' is true just in case God is omnipotent - and, in general, we should be able to work out the truth conditions of an indicative religious sentence from what is said. This is disputed, however, by reductionists and subjectivists.

Reductionists propose that for the sentences under discussion - we can call these (following Dummett, 322) the disputed class of sentences their truth conditions are given by some other class of sentences, or the reductive class. This is a familiar strategy in many areas of philosophy. Phenomenalists, for example, contend that statements about the external world can be analysed in terms of statements about our actual or possible experiences; some behaviourists take sentences about mental states to be reducible to sentences about behaviour and dispositions. There are also well-know varieties of religious reductionism. Consider, for example, the gods that populate classical literature. There is some attraction, at least to the modern monotheistic or secular reader, of interpreting talk about divine intervention in Homer, for instance, as representing natural forces and human temperament. A naturalistic reduction allows for a reading of Homer free from extravagant and implausible superstitions about the Olympian gods. Naturalistic reductions of theistic religious language have been proposed by, among many others, Julian Huxley and Henry Wieman. According to Huxley, monotheistic and other central Christian beliefs are ways of talking about phenomena for which we cannot find empirical explanations. God, for instance, is identified with the forces of nature. According to Wieman, God is 'that interaction between individuals, groups, and ages which generates and promotes the greatest possible mutuality of good' (13). ${ }^{5}$

A successful reductionist theory promises not only to take an area of discourse that appears (to the reductionist) to have a metaphysically dubious subject matter and interpret in a way that is (according to the reductionist) metaphysically above suspicion, but also to do this without eliminating or even without modifying the discourse in question. So for theologians in the religious naturalist tradition who aim to understand theology within a naturalist framework - and among whom Weiman is an important early figure - religious reductionism seems an attractive theory (for a review of their work see Frankenberry). However, the problems that face reductionism in the religious case appear insurmountable. Even if the reductionist can specify naturalistic truth conditions for some 
sentences about God, how will 'He will come again in glory to judge the living and the dead, and his kingdom will have no end', or most statements of theology and doctrine be interpreted? If there is no plausible reductionist analysis of such statements, then they will have to be regarded by the reductionist as being in error. But if most religious statements are false, why continue to maintain a reductionist analysis for a handful of them? If religious discourse is so error-prone after a reductionist analysis, there seems no advantage in adopting reductionism over atheism. ${ }^{6}$

A notable variety of reductionism is subjectivism. According to the religious subjectivist, religious sentences are about the states of mind of religious believers. That is, what distinguishes subjectivism from other kinds of reductionism is that the reductive class of sentences concern human psychological states. ${ }^{7}$ For example, the theologian Friedrich Schleiermacher construed talk of God in terms of a 'feeling of absolute dependence'. In the late 1920s, Wittgenstein was also sympathetic to a subjectivist theory, though there is little hint of it in his subsequent work on the topic. In 'A Lecture on Ethics' from 1929, Wittgenstein distinguishes between a 'wonder at the existence of the world' and 'the experience of feeling absolutely safe', and proposes:

the first of [these experiences] is, I believe, exactly what people were referring to when they said that God had created the world; and the experience of absolute safety has been described by saying that we feel safe in the hands of God. A third experience of the same kind is that of feeling guilty and again this was described by the phrase that God disapproves of our conduct.

Religious subjectivism is a type of reductionism and consequently suffers from the same problem; the theory also has difficulty in accounting for disagreement between religious beliefs (see Smith, 41-43 - his discussion concerns ethical subjectivism but can be generalised to religious subjectivism). Although hardly anyone finds subjective analyses remotely plausible it is important, as we will see, to distinguish the theory.

\section{Expressivism}

Are religious sentences truth apt and do they have propositional content? Here, again, it may seem that the correct theory is obvious. The following claims seem quite harmless: indicative religious sentences represent the 
world as being a certain way, they are true or false according to whether they do so successfully, they are typically used to make assertions about matters of fact, and when sincerely uttered they convey the speakers' beliefs. However, expressivist theories of religious language - also called 'non-cognitivist' or 'emotivist' - reject at least some of these contentions. Religious expressivism has frequently been defended in philosophy but has never received widespread acceptance; it has more consistent pockets of support in theology.

\subsection{Varieties of expressivism}

According to some religious expressivists religious sentences are not used to make assertions, rather, religious utterances are akin to commands, practical recommendations (Santayana, 3-14), practical prescriptions (Le Roy), the articulation of principles of conduct (Hare, Arnold), or evocatives aimed at prompting piety and righteousness (Spinoza, Berkeley, 286-303). ${ }^{8}$ On this view, religious discourse is quite distinct from ordinary descriptive discourse - since religious discourse does not even employ assertoric speech acts, it is not in the business of representing the world (truly or falsely).

However, according to a second variety of expressivism, religious discourse is (at least on the surface) much like ordinary descriptive discourse. What distinguishes religious discourse from, say, discourse about physical objects is that religious utterances do not express beliefs. Instead, they express plans or intentions (Braithwaite), stances (Hare), attitudes (Evans) and ways of seeing the world (van Buren), emotions (Arnold), or faith (construed as a mental state more akin to devotion than belief - Rhees; Holmer). These various mental states, which I will call 'attitudes', are taken to be about or directed towards 'the world', to one's own past or future behaviour, to the behaviour of others, etc.; that is, these attitudes do not themselves have religious content (if they have propositional content at all). There is also a plausible (variety-2) expressivist reading of Wittgenstein. In Culture and Value he describes religion as 'a passionate commitment to a system of reference' (64), and in his lectures he characterises religious people as living their lives according to certain 'pictures' (actually believing that those pictures are true does not seem to be crucial). A number of wittgensteinians have pursued this expressivist line - B. R. Tilghman for example, and Dewi Phillips in his early work in the 1960s (for a review see Scott 'Wittgenstein and Realism').

Expressivism is highly contentious; its very mention is likely to prompt irritation or derision from unsympathetic philosophers of religion. However, critics of religious expressivism typically have in their sights 
variety-1 versions of the theory. For example, it's a standard objection to expressivism that it seems unable to give an adequate account of a religious person's claim that a statement about God is true (Tilley, 37). This seems a serious problem for the first type of expressivism: commands and prescriptions are not true or false. The second type of expressivism, in contrast, embraces a non-revisionary account of religious language - including talk of truth and falsity, religious facts, reality, etc. but sees this talk as expressive of attitudes rather than beliefs. As such, it offers a more promising theory of what religious claims mean. Readers investigating the literature, however, should be advised that expressivists are themselves sometimes unclear on which type of theory they are propounding. For a review of other objections to expressivism raised in philosophy of religion see Scott ('How to Defend Religious Realism').

Expressivism is sometimes confused with subjectivism (see, for example, Phillips Religion without Explanation, 144). But it should be clear that, despite some superficial similarities, this cannot be right. Subjectivists maintain that religious statements express beliefs and are truth-apt - but their truth-conditions are given by statements about our psychologies to which they are reduced. Expressivists maintain, in contrast, that religious statements are either not truth-apt or express attitudes. The two theories are therefore inconsistent.

\subsection{Why would anyone be an expressivist?}

There have been three main motivations for religious expressivism.

(a) The most discussed motivation for expressivism, though now of mainly historical interest, stems from a project influenced by the work of the Vienna Circle - a late 1920s/early 1930s grouping of philosophers to identify general principles for 'meaningful' statements. Religious statements, along with those of ethics and aesthetics, usually fell short of the proposed criteria (Carnap, Ayer). For example, according to Ayer's 'Empirical Verification Principle' statements are 'meaningless' if they are neither tautologies nor empirically verifiable: a principle which, Ayer argued, neither religious nor ethical statements satisfy. Ayer went on to propose an 'emotivist' theory of ethics. Even though ethical claims are 'factually contentless' they may still be used to express our attitudes of approval or disapproval, and to evoke similar attitudes in others; religious discourse, Ayer thought, should simply be eliminated. Expressivists impressed by these arguments - including philosophers Braithwaite and Hare and theologians Miles and van Buren - generally accept that religious statements are 'factually contentless' but attempt to develop a theory akin to emotivism for religion. 
The problems with Ayer's theory have been repeated so often, I refer the reader to Alston ('Religious Language and Verificationism') for a concise summary; that something is seriously awry with this theory is indicated by the fact that the empirical verification principle is itself neither a tautology nor empirically verifiable. Religious expressivist theories developed on the model of Ayer's ethical emotivism, such as Braithwaite's, also run into serious problems. Perhaps the most obvious failing in Braithwaite's theory is that he only identifies one intention being voiced in every religious utterance - an intention to pursue an agapeistic form of life - from which seems to follow the bizarre consequence that all purely religious claims have the same meaning. Further objections to Braithwaite that are widely seen as demolishing his theory are given by Swinburne in The Coherence of Theism (88-91).

(b) George Berkeley argues we lack any clear ideas corresponding to the central terms of the Christian mysteries, such as the Trinity, grace and original sin (Section VII); he contends that this is shown by introspection. The purpose of talking of the Trinity, etc., according to Berkeley, is primarily to encourage believers to act according to Christian principles:

Original sin, for instance, a man may find it impossible to form an idea of in abstract, or of the manner of its transmission; and yet the belief thereof may produce in his mind a salutary sense of his own unworthiness, and the goodness of his Redeemer: from whence may follow good habits, and from them good actions, the genuine effects of faith. (VII: 10)

However, Berkeley restricts his expressivism to talk about the Christian mysteries; for all other areas of religious discourse he is a cognitivist (he believes, for example, that the existence of God is demonstrable). Ronald Hepburn is more radical: he claims that all talk of God is deeply paradoxical and as such not factually informative, but nevertheless it 'expresses the way of life chosen, and inspires the believer to implement it in practice'. (195) The motivation for expressivism suggested by both of these accounts is that this is that religious sentences - or at least some of them - either lack or have incomplete propositional content: a full account of their meanings needs to be filled out by reference to their practical role.

(c) A standard line of argument used to support ethical expressivism (the view that statements about what is good or bad express approval or disapproval) is based on the plausibility of internalism about ethics: the apparent necessary connection between a moral judgement that 
$x$ is good and a motivation to do $x$ or promote $x$. There are two related arguments. The first is that moral judgement motivates whereas beliefs do not, so therefore a moral judgement is not a belief but a motivational state. (Blackburn) The second is that expressivism, by proposing that moral statements express attitudes, has the simplest explanation for the link between moral judgement and motivation. Since there is also at least some prima facie plausibility to religious internalism, there should be entirely isomorphic arguments available to the religious expressivist. However, this remains a relatively unexplored area. Berkeley suggests a similar line of argument when he asserts that 'Faith, I say, is not an indolent perception, but an operative persuasion of mind, which ever worketh some suitable action, disposition, or emotion in those who have it' (VII: 10), and Phillips frequently claims that there is an 'internal' connection between religious belief and the 'fruits of belief' (which includes religious behaviour - see his Wittgenstein and Religion). Swinburne is one of few philosophers of religion to attack this issue head on, arguing for religious externalism - the theory that religious beliefs are not essentially motivational (90)

\section{Minimalism}

I indicated above that there is a plausible expressivist reading of Wittgenstein. However, there is a different and more widely accepted interpretation available, which I will call minimalism, that has been defended by Hilary Putnam and in his later (post-1990) work by Dewi Phillips. There are two central ideas to this alternative view. First, religious discourse - and other areas of discourse - is understood as a language game or collection of language games with its own internal standards of truth, justification and reference. These are identified by looking at the practices of those who engage in the discourse. So, for example, empirical evidence may be a standard of justification that is operative in discourse about physical objects, whereas evidence from a sacred text or the word of a religious authority may be a standard of justification operative in (some areas of) religious discourse. Second, there are no robust cross-discourse standards of truth and reference (hence 'minimalism'); rather, truth and reference are taken to be constituted (at least in part) by these discourse specific features. ${ }^{9}$ So the minimalist allows that religious claims are true, religious expressions refer, etc., but proposes that what counts as a true sentence or referring expression depends on standards that are local to the discourse in question. 
Most critical discussion of minimalism focuses on its supposed fideistic implications: the minimalist, in effect, partitions religious discourse from other regions of discourse, immunising it to criticism on non-religious grounds (Nielsen). However, there are two interesting upshots of minimalism that have received less attention. The first of these concerns reference. The intuitive difference between minimalist and nonminimalist conceptions of religious reference is that the former takes a term like 'God' to refer if it occurs as a singular term in a sentence that is justified (according to the standards of religious discourse), whereas the latter sees the reference of 'God' as a relationship between the expression and reality that is independent of mind and language. Alston's application of a causal theory of reference to 'God' is an example of the nonminimalist tradition; theologian Gordon Kaufman's 'constructivist' theology, that relates talk of God to human practices and imaginations, is an example of the latter (see In Face of Mystery, and 'Mystery, God and Constructivism' for a recent statement of his position). Minimalists, it should be noted, are committed neither to Kaufman's theology nor the specifics of his analysis.

The second issue concerns truth. According to the minimalist, truth in a discourse is tied to the standards of justification in that discourse. Consequently, if a statement outstrips - even in principle - our ability to justify it, the minimalist will not be able to assert that it is either true or false. Since lots of religious statements seem to outstrip our ability to justify them even in principle, it seems that the religious minimalist must reject the principle of bivalence, that is, the principle that for any religious statement it is either true or false. If this is right, then minimalism is prima facie inconsistent with the religious belief that God is omniscient, since if God is omniscient then (it seems) He will know of any statement whether it is either true or false. This argument was introduced by Dummett, and has recently been examined in detail by Michael Scott and Graham Stevens.

\section{Religious Language and the Philosophy of Religion}

Although religious language has been a less active field of research in the last few decades than religious epistemology and metaphysics, the questions it addresses are in some respects more fundamental. Specifically, certain facts about the truth and content of religious sentences have to be in place for familiar questions about metaphysics and epistemology to come into play. For example, work on metaphysical issues such as the nature and existence of God and on epistemological issues such as the rationality of religious belief takes for granted the 
comprehensive failure of expressivist theories of religious language accounting, perhaps, for the sometimes vituperative reaction to them. In general, researchers working in cognate areas of philosophy of religion take religious discourse to conform to a conventional semantic theory of the kind thought to hold for ordinary descriptive discourse.

A primary objective of a theory of religious language, as I have indicated, is to identify the correct semantic theory of religious language - conventional or not - supplemented by an account of the important pragmatic features of the uses of religious sentences. To this extent, philosophical work on this issue is non-revisionary. That is, we are looking for an account of what religious sentence mean and how they are used, rather than saying what they should mean or proposing any modifications to how they are used. Revisionary accounts are typically driven by metaphysical or epistemological considerations - they are also often theological - and as such fall outside the main purview of work on religious language. However, in some cases, metaphysics, epistemology and language are so closely interconnected that they deserve special attention.

\subsection{Metaphor}

Early writers on religious language, notably the church fathers, were concerned with whether a predicate used of God such as 'good' has the same sense when it used in a non-religious context (is 'univocal'), a different but related sense ('analogical'), or an entirely different sense ('equivocal'). More recent attention has focussed on the role of metaphor in religious discourse. It's sometimes claimed that all religious claims are metaphorical (see Sally McFague, Marcel Sarot), but this seems to rely on introducing a non-standard understanding of 'metaphor'. Standardly, we can distinguish 'God created the world', where the speaker means what is said, from 'The Lord is my shepherd', where a speaker uses a (false) sentence to convey something else. One line of enquiry, pursued by Frederick Ferre and more recently by Janet Soskice, concerns the relationship between metaphors in religion and in science. A second line of discussion, of particular relevance here, concerns the argument that all true utterances about God are metaphorical. This position, one recent exponent of which is Anthony Kenny, is primarily motivated by metaphysics: God is 'transcendent' and as such nothing can be literally predicated of Him. However, why it is that metaphorical talk should be better placed to be informative about God is not made clear. Moreover, as Alston has argued, metaphors posit some kind of comparison that can at least in part be literally specified. (Divine Nature and Human Language) 


\subsection{Fictionalism}

Fictionalists think that we should be agnostic or atheistic about religion but argue that there is merit in 'accepting' a religion and engaging with it - in the way, perhaps, that we can engage with a fiction - because to do so yields moral and social benefits. This position has been given its clearest exposition by Peter Lipton, who models his account on Bas van Fraassen's fictionalism about scientific theories (see also earlier accounts of religious fictionalism by Robin LePoidevin and Don Cuppit).

Religious fictionalism is a particularly interesting theory, not least because it is plausible that many religious 'believers' are themselves in the position of being sceptical about the truth of their beliefs but remain active members of a religious community. Is this a morally and philosophically defensible position? There has been a great deal of recent work on fictionalism in different fields of philosophy, notably ethics and mathematics - Mark Kalderon (ed) provides a useful guide to research.

\section{Future directions}

Religious language has been a fairly quiet field in recent years, whereas corollary issues in philosophy of language have developed apace. On the one hand, this exposes some serious lack of clarity in the leading theories about religious language on issues that are - in contemporary philosophy of language - quite fundamental: whether a theory is revisionary or nonrevisionary, for instance. On the other hand, this opens up a number of interesting future directions for research in areas that are relatively unexplored. I have already mentioned fictionalism, reference and the logic of religious language, but the same could be said for metaphor and expressivism. There is a substantial current debate about expressivism that largely excludes consideration of religion. Notably, Simon Blackburn - whose seminal 1984 introduction to philosophy of language Spreading the Word kick-started this debate - has touched on the issue of religious expressivism (also see his 'Religion and Ontology'); even so the issue has been barely touched on. The opportunity is available not just for philosophers of religion to draw on the resources of philosophy of language, but for philosophers of language to consider religious discourse for its distinctive problems and its contrasts with ethical and scientific discourses. 


\section{Works cited}

Alston, William. Divine Nature and Human Language. Ithaca: Cornell University Press, 1989.

Alston, William. 'Religious Language and Verificationism'. The Rationality of Theism. Ed. Paul Moser, Paul Copan. Routledge, 1993: 1734.

Alston, William. 'Religious Language'. The Oxford Handbook of Philosophy of Religion. Ed. William Wainwright. Oxford: Oxford University Press, 2005: 220-244.

Arnold, Matthew. Literature and Dogma. London: Smith, Elder, 1873.

Ayer, A. J. Language, Truth and Logic. London: Victor Gollancz, 1936. Berkeley, G. Alciphron or the Minute Philosopher. The Works of George Berkeley, vol. 3. Ed. A. Luce and T. Jessop. London: T. Nelson, 1732/1950.

Blackburn, Simon. Spreading the Word. Oxford: Oxford University Press, 1984.

Blackburn, Simon. 'Religion and Ontology'. Realism and Religion. Eds. Andrew Moore and Michael Scott. Aldershot: Ashgate, 2007.

Braithwaite, R. B. 'An Empiricist's View of the Nature of Religious Belief'. The Philosophy of Religion. Ed. B. Mitchell. Oxford: Oxford University Press, 1955.

Cappelen, Herman and LePore, Ernest. Insensitive Semantics. Malden, Mass: Blackwell, 2005.

Carnap, Rudolf. 'Religious Language is Meaningless'. Logical Positivism ed. A. J. Ayer. The Free Press, 1959: 60-81.

Cupitt, Don. Taking Leave of God. London: SCM Press, 1980.

Dummett, Michael. The Logical Basis of Metaphysics. London:

Duckworth, 1991.

Evans, Donald. The Logic of Self-Involvement. London: SCM Press, 1963.

Frankenberry, Nancy. 'Religious Empiricism and Naturalism'. A Companion to Pragmatism. Eds. John Shook, Joseph Margolis. Oxford: Blackwell, 2005.

Hare, R. M. Essays on Religion and Education. Oxford: Oxford University Press, 1992.

Hepburn, Ronald. Christianity and Paradox. London: Watts, 1958. Holmer, Paul. 'The Nature of Religious Propositions'. The Review of Religion 19 (1955): 136-49.

Huxley, Julian. Religion without Revelation. London: E. Benn, 1957. Kaufman, Gordon. In Face of Mystery. Cambridge, Mass.: Harvard University Press, 1993. 
Kaufman, Gordon. 'Mystery, God and Constructivism'. Realism and Religion. Eds. Andrew Moore and Michael Scott. Aldershot: Ashgate, 2007.

Kalderon, Mark Eli (ed). Fictionalism in Metaphysics. Oxford: Clarendon Press, 2005.

LePoidevin, Robin. Arguing for Atheism. London: Routledge, 1996.

Lipton, Peter. 'Science and Religion: The Immersion Solution'. Realism and Religion. Eds. Andrew Moore and Michael Scott. Aldershot:

Ashgate, 2007.

Miles, Thomas. Religion and the Scientific Outlook. London: Allen and Unwin, 1959.

Le Roy, Edouard. 'Religious language is "practical"'. The Problem of Religious Language. Ed. M. J. Charlesworth. Englewood Cliffs, NJ:

Prentice Hall, 1974. 171-196.

Nielsen, Kai. 'Wittgensteinian Fideism'. Philosophy 42 (1967): 191-209.

Phillips, D. Z. Religion Without Explanation. Oxford: Blackwell, 1976.

Phillips, D. Z. Wittgenstein and Religion. London: Macmillan, 1993.

Phillips, D. Z. 'Philosophers Clothes'. Relativism and Religion. Ed. C. M. Lewis. London: Macmillan, 1995.

Putnam, Hilary. Renewing Philosophy. Cambridge, Mass.: Harvard University Press, 1992.

Santayana, George. The Life of Reason, vol III: Reason in Religion. New York: Scribner, 1905.

Schleiermacher, Friedrich. The Christian Faith. Edinburgh: T \& T Clark, 1928.

Scott, Michael and Stevens, Graham. 'Is God an Antirealist?'. American Philosophical Quarterly 44 (2007): 383-398.

Scott, Michael. 'Wittgenstein and Realism'. Faith and Philosophy 17 (2000): 170-190.

Scott, Michael. 'How to Defend Religious Realism'. Faith and Philosophy 23 (2006): 314-336.

Scott, Michael and Stevens, Graham. 'Is God an Antirealist?'. American Philosophical Quarterly 44 (2007): 283-298.

Smith, Michael. The Moral Problem. Oxford: Blackwell, 1994.

Soskice, Janet. Metaphor and Religious Language. Oxford: Clarendon, 1985.

Soskice, Janet. 'Religious Language'. A Companion to Philosophy of Religion. Eds. P. Quinn and C. Taliaferro. Oxford: Blackwell, 1999. Spinoza, Benedictus de. Tractatus Theologico-Politicus. Tr. R. Elwes. New York: Dover Publications, 1951.

Stiver, Dan. The Philosophy of Religious Language: sign, symbol and story. Oxford: Blackwell, 1996. 
Swinburne, Richard. The Coherence of Theism. Oxford: Oxford University Press, 1993.

Tappolet, C. 'Mixed Inferences: A Problem for Pluralism about Truth Predicates'. Analysis 57 (1997): 382-5.

Tilghman, B. R. 'Isn't belief in God an attitude?'. International Journal for Philosophy of Relition 43 (1998): 17-28.

Tilley, Terrence. Talking of God. New York: Paulist Press. 1978.

Tillich, Paul. The Shaking of the Foundations. Harmondsworth: Penguin, 1962.

Van Buren, Paul. The Secular Meaning of the Gospel. London: SCM Press, 1963.

Van Fraassen, Bas. The Scientific Image. Oxford: Oxford University Press, 1980.

Wieman, Henry. Is There a God? Ed. Charles Clayton Morrison.

Chicago: Willett, Clarke \& Co. 1932.

Wieman, Henry and Meland, Bernard. American Philosophies of Religion. Chicago: Willett, Clarke \& Co. 1936.

Williamson, Timothy. 'A Critical Study of Truth and Objectivity'. International Journal of Philosophical Studies 30 (1994): 130-44. Wittgenstein, Ludwig. Lectures and Conversations on Aesthetics, Psychology and Religious Belief. Ed. C. Barrett. Oxford: Blackwell, 1966.

Wittgenstein, Ludwig. 'A Lecture on Ethics. Philosophical Occasions.

Ed. J. Klagge and A. Nordmann. Indianapolis: Hackett, 1993. 36-44. Wittgenstein, Ludwig. Culture and Value, revised edition. Ed. G. H. von Wright, tr. P. Winch. Oxford: Blackwell, 1994.

Wright, Crispin. Truth and Objectivity. Cambridge, Mass.: Harvard University Press, 1992.

Wynn, Mark. 'Religious Language'. Companion Encyclopedia of Theology. Ed. J. Houlden, Peter Byrne. London: Routledge, 1995. 413432. 
${ }^{1}$ Note that on most conceptions of semantics, context may play a role in fixing the content of a sentence that includes context sensitive expressions, such as indexicals. In the sentence 'I am happy', for example, the interpretation of the indexical ' $I$ ' will vary according to the identity of the speaker. Pragmatic theories admit the intrusion of context on the content of a sentence by way of the interpretation of expressions that are not standardly taken to be context sensitive.

${ }^{2}$ An utterance is taken here to be the production of a token sentence. Utterances are not tied to specifically verbal communication.

${ }^{3}$ Wittgenstein is often seen as allied to pragmatic accounts and rejecting semantic theories tout court by virtue of his oft cited claim that the meaning of a word - 'in a large class of cases' - can be identified with its use. Wittgenstein speaks here of words rather than sentences, but the implication of this position is that in the interpretation of a sentence most if not all of its constituent expressions would have to be treated as context sensitive. See fn. 1.

${ }^{4}$ Note that whether, and to what extent, metaphor is a pragmatic phenomenon is a contentious issue.

${ }^{5}$ This is not the only formulation that Wieman offers. Cf. Wieman and Meland, 43.

${ }^{6}$ Huxley himself seems to have intended his naturalistic proposal as a basis for rejecting religious discourse in favour of talk about the naturalistic phenomena that give rise to religious belief.

${ }^{7}$ If, as is usually proposed, the subjective states of mind in question are the speaker's, then religious expressions will function like indexicals. For example, if the subjectivist analysis of 'God is omnipotent' is 'I have a feeling of absolute dependence', then the utterance of the former will be true in some context of utterance if and only if the latter is also true in that context.

${ }^{8}$ Note that not all of these authors are offering expressivism that comprehends all religious discourse; some are restricted to limited classes of religious claims.

${ }^{9}$ Note that the minimalist is not committed to saying that 'true' or 'refers' is ambiguous - Timothy Williamson and Christina Tappolet have convincingly argued that this position is untenable. Rather, the minimalist can argue that while there are necessary and sufficient conditions for truth, reference, etc., these are sufficiently minimal that any reasonably disciplined discourse will satisfy them (for more discussion, see Crispin Wright). 